Jānis Kudiņš, Irēna Kokina

\title{
ECONOMIC INEQUALITY AMONG OLDER PEOPLE IN THE EUROPEAN UNION
}

\author{
DOI: https://doi.org/10.9770/szv.2021.1(5)
}

For citation: Kudinšs J., Kokina I. (2021) Economic inequality among older people in the European Union. Sociālo Zinātņu Vēstnesis / Social Sciences Bulletin, 32(1): 98-121. https://doi.org/10.9770/szv.2021.1(5)

Citēšanai: Kudiņš J., Kokina I. (2021) Ekonomiskā nevienlīdzība gados vecāku cilvēku vidū Eiropas Savienībā. Sociālo Zinātņu Vēstnesis, 32(1): 98-121. https://doi.org/10.9770/ szv.2021.1(5)

This study is aimed to investigate economic inequality among older people in the European Union based on empirical data. The object of the research is older people, which in the framework of this study includes persons aged 65 and over. The novelty of this study is a scientifically based conceptual understanding of economic inequality among people, which [economic inequality] is broader than just income inequality. The uniqueness of this study lies in the fact that the authors did not investigate the economic performance of older people in comparison with other age groups or the general population (there are many studies devoted to this), but they investigated economic inequality among older people versus economic inequality in other age groups / in the general population (subject to data availability). The methodological basis of this research is formed by three approaches to conceptual understanding of economic inequality among people: the income-wealth approach, the resource-capital approach and the capability approach. The analysis of statistical and sociological data for the EU countries in the framework of complementary methodological approaches made it possible for the authors to conclude that both income and wealth are distributed among older people as unequally as this also occurs in other age groups of the population. The only statistically significant difference that the authors managed to identify concerns the capability to convert the economic resources at the disposal of people into economic capital: among older people there is more inequality in the degree of capitalization of economic resources than among younger people. Thus, in the European Union, economic inequality (except for only one its aspect - the degree of economic resources' capitalization) is not a distinctive feature of the age group of older people, but is practically the same as in other age groups or in the general population. Empirical evidence suggests that economic inequality is not accumulated over the course of a lifetime, but rather carries over from one period of life to another.

Key words: older people, economic inequality, income-wealth approach, resource-capital approach, capability approach.

\section{Ekonomiskā nevienlīdzība gados vecāku cilvēku vidū Eiropas Savienībā}

Šis pētījums ir veltîts ekonomiskās nevienlīdzības izpētei gados vecāku cilvēku vidū Eiropas Savienībā un balstās uz empīiskajiem datiem. Pētījuma objekts ir vecāka gadagājuma cilvēki, kas šì pētījuma ietvaros iekḷauj personas no 65 gadu vecuma. Pētījuma novitāti veido zinātniski pamatota konceptuāla izpratne par cilvēku ekonomisko nevienlīdzību, kas [ekonomiskā nevienlīdzība] ir plašāka nekā ienākumu nevienlīdzība. Šì pētījuma unikālā iezìme ir tā, ka autori pētīja nevis gados vecāku cilvēku ekonomisko stāvokli salīdzinājumā ar citām vecumgrupām 
vai iedzīvotājiem kopumā, bet gan tieši ekonomisko nevienlīdzību vecāka gadagājuma cilvēku vidū salīdzinājumā ar ekonomisko nevienlīdzību citās vecumgrupās vai iedzīvotāju vidū kopumā (atkarībā no datu pieejamības). Šì pētījuma metodologisko pamatu veido trīs pieejas cilvēku ekonomiskās nevienlīdzības konceptuālai izpratnei: ienākumu-bagātîbas pieeja, resursu-kapitāla pieeja un spēju pieeja. Statistisko un sociologisko datu analīze par Eiropas Savienības valstīm augstākminēto metodolog̣isku pieeju ietvaros ḷāva autoriem secināt, ka gan ienākumi, gan bagātība vecāka gadagājuma cilvēku vidū tiek izkliedēti tikpat nevienmērīgi kā citās iedzīvotāju vecumgrupās. Vienīgā statistiski nozīmīgā atškikirība, kuru autoriem izdevās identificēt, attiecas uz cilvēku spēju (vai iespējamību) viṇu rīcībā esošos ekonomiskos resursus pārvērst ekonomiskajā kapitālā: gados vecāku cilvēku vidū ekonomisko resursu kapitalizācijas pakāpe tiek izkliedēta nevienlīdzīgāk, nekā gados jaunu cilvēku vidū. Tādējādi Eiropas Savienībā ekonomiskā nevienlīdzība (izṇemot tikai vienu tās aspektu - resursu kapitalizācijas pakāpi) nav vecāka gadagājuma cilvēku vecumgrupas īpatnība, bet ir praktiski vienāda visās vecumgrupās. Empïriski dati liecina par to, ka ekonomiskā nevienlīdzība neuzkrājas dzīves gaitā, bet gan tiek pārnesta no viena dzives perioda uz otru.

Atslēgas vārdi: gados vecāki cilvēki, ekonomiskā nevienlīdzība, ienākumu-bagātības pieeja, resursu-kapitāla pieeja, spēju pieeja.

\section{Экономическое неравенство среди пожилых людей в Европейском Союзе}

Данное исследование посвящено изучению экономического неравенства среди пожилых людей в Европейском Союзе и проведено на основании эмпирических данных. Объектом исследования являются пожилые люди, к которым - в рамках данного исследования - относятся лица от 65 лет и старше. Новизну исследования составляет научнообоснованное концептуальное понимание экономического неравенства между людьми, которое [экономическое неравенство] шире, чем просто неравенство доходов. Уникальной особенностью данного исследования является то, что авторы изучали не экономическое положение пожилых людей в сравнении с остальными возрастными группами или населением в целом, но именно экономическое неравенство среди пожилых людей в сравнении с экономическим неравенством среди других возрастных групп или населения в целом (в зависимости от наличия данных). Методологическую основу данного исследования составляют три подхода к концептуальному пониманию экономического неравенства между людьми: подход «доход-богатство», ресурсный подход и подход возможностей. Анализ статистических и социологических данных по странам Европейского Союза в рамках дополняющих друг друга методологических подходов позволил авторам сделать вывод о том, что и доходы, и богатство распределяются среди пожилых людей настолько же неравномерно, насколько это происходит и в других возрастных группах населения. Единственное статистически значимое отличие, которое удалось выявить авторам, касается способности (или возможности) превращать имеющиеся в распоряжении людей экономические ресурсы в экономический капитал: среди пожилых людей наблюдается большее неравенство в степени капитализации экономических ресурсов, чем среди более молодых людей. Таким образом, в Европейском Союзе экономическое неравенство (за исключением лишь одного аспекта - степени капитализации экономических ресурсов) не является особой отличительной чертой возрастной группы пожилых людей, а практически одинаково во всех возрастных группах. Эмпирические данные показывают, что экономическое неравенство не накапливается в течение жизни, а скорее переносится из одного жизненного периода в другой.

Ключевые слова: пожилые люди, экономическое неравенство, подход «доход-богатство», ресурсный подход, подход возможностей. 


\section{Introduction and literature review}

In the authors' opinion, there are two main areas of scientific research related to economic inequality: inequality among territories (regions, countries, etc.) and inequality among social groups, households, people. The first one is investigated by almost all researchers in the sphere of regional economics (Granberg et al. 1998; Granberg 1999; Rice, Venables 2004a, 2004b; Kim 2008; Kuttor 2009; Karwat-Wozniak 2011; Cochrane, Perrella 2012; Kvícalova et al. 2014; Glinskiy et al. 2017; Selivanova-Fyodorova et al. 2019; Selivanova-Fjodorova 2020 and many others). In turn, inequality among social groups, households, people is also topical issue for economists and sociologists (Kuznets 1955; Dworkin 1981a, 1981b; Kovacevic 2010; Mensikovs, Lavrinovica 2011; Piketti 2015; Mensikovs et al. 2020, Kozyreva et al. 2021 and many others). Some researchers compare spatial and social disparities concluding that, for example, in Latvia and Hungary, the territorial inequality is less than social one (Krastins 2000; Meusburger 2001).

In turn, economic inequality among older people of the world was investigated by the United Nations Department of Economic and Social Affairs (UNDESA) programme on ageing concluding that "economic inequalities exist both between older persons and the rest of the population and among older persons themselves, leaving many excluded from prosperity, resources and decent work" (UNDESA 2016). The Age International, a charity devoted to helping older people in developing countries, conducted the study "Facing the facts: The Truth About Ageing and Development" (Age International 2014) stressing that "in almost every country of the world, the proportion of older people in the population is increasing. By 2050, around 2 billion people in the world will be aged 60 years or over, with 400 million of them aged 80 years and over. Some $80 \%$ of them will be living in what are now low or middle-income countries" (Chan 2014). R. Jolly argues that "inequalities accrue and get reinforced over a person's life. They come home to roost in later years, often exacerbating each other and causing greater disadvantage. Poverty, poor health, discrimination and marginalisation are all-too common realities for many older people in both developing and developed countries" (Jolly 2014).

Thus, the object of this study is older people. Within this study, older people are defined based on the following three criteria: 1) receiving an old-age pension; 2) the availability of statistical data for the selected age group; 3 ) the world practice in defining the older people. Most countries have accepted age of 65 years as the chronological basis for defining the older person (Orimo et al. 2006; Alpteker 2012).

The subject of this study is the economic inequality among older people in the European Union. On 1 January 2019, the inhabitants of the European Union 65 years old and more (65+ age group) amounted to $20.3 \%$ of the total number of the EU-27 population (446.8 million people) and increased by 0.3 percentage points compared with the previous year and by 2.9 percentage points - compared with 10 years earlier (Eurostat 2021). The period of this research is limited to the last 10 years - from 2011 to 2020 , which is a sufficient time interval for understanding the current situation with economic inequality among older people in the European Union. 
Comparison by age groups of statistical data on the increase in disposable income per household member for the period from 2011 to 2019 shows that in Latvia, the $65+$ age group lags behind most in terms of income growth, since income growth in this age group over the past 10 years is the lowest (Table 1 ).

Table 1

\section{Mean disposable income per household member by age group in Latvia,} euro, 2011 and 2019

\begin{tabular}{cccc}
\hline Age groups & 2011 & 2019 & Changes 2019/2011, \% \\
\hline $0-15$ & 255.25 & 512.35 & +100.7 \\
\hline $16-24$ & 276.21 & 557.89 & +102.0 \\
\hline $25-34$ & 344.28 & 702.73 & +104.1 \\
\hline $35-44$ & 308.32 & 622.65 & +101.9 \\
\hline $45-54$ & 314.03 & 634.64 & +102.1 \\
\hline $55-64$ & 346.16 & 627.82 & +81.4 \\
\hline $65+$ & 295.28 & 486.98 & +64.9 \\
\hline Total & 304.51 & 582.82 & +91.4 \\
\hline
\end{tabular}

Source: the authors' calculations based on the Central Statistical Bureau of Latvia 2021.

These results correspond with the European Commission Employment, Social Affairs and Inclusion unit's research "Demography and Inequality", where is argued that "income inequality in Europe is sensitive to population ageing, since the elderly face high poverty risks and represent a growing share of the population" (European Commission 2013).

Latvian researcher A. Grinfelde in her Doctoral Thesis "Life Quality of Pensioners in Latvian Regions" argued that "pensioners' perceptions of a good life in Latvia are mainly associated with material provision, good health and good relationships with the closest people: family members, friends and neighbours" (Grinfelde 2010). She also found that the poorest Latvian pensioners live in Latgale region and Vidzeme region. Four out of ten pensioners in Vidzeme region and five out of ten pensioners in Latgale region cannot afford one of the following goods: telephone, colour TV, washing machine, and car. More than a half of pensioners in Vidzeme region $(54.8 \%)$ and Latgale region $(59.7 \%)$ live in inadequate or not well-facilitated lodging, comparing to Pieriga region, where pensioners are twice less unsatisfied with housing condition. Material unsafety is intensified by the fact that $92 \%$ of those living in Latgale region and Vidzeme region barely can "make the ends meet" (Grinfelde 2010).

All aforementioned research findings and statistical data are about economic disparities between older people and the rest of the population as well as spatial disparities among older people, and not about economic inequality among older persons themselves. The only study the authors have found on economic inequality in the $65+$ age group versus economic inequality in the general population is the OECD research "Preventing Ageing Inequality", which examined how population ageing and rising inequalities in OECD countries have been developing and interacting, both within 
and across generations (OECD 2017). Key findings of this study in relation to the issue investigated in this article are as follows (OECD 2017):

- income inequality has been rising from one generation to the next at the same age in two-thirds of countries, in particular among younger groups for which inequality is nowadays much higher than for the older people;

- on average, about two-thirds of lifetime earnings inequality passes on to pension inequality - from less than $25 \%$ for many Anglo-Saxon countries to more than $85 \%$ in about one-third of OECD countries;

- low-earners tend to have a lower life expectancy than high earners and this reduces further their total pensions by about $13 \%$. Raising the retirement age tends to widen inequality in total pensions between low and high earners, but the impact is small;

- annual pension payments to the over-65s are about $27 \%$ lower for women on average, and old-age poverty is much higher among women than among men;

- income inequality among those older than 65 years varies widely across countries.

This study is aimed to investigate economic inequality among older people in the European Union based on empirical data. The novelty of this study is a scientifically based conceptual understanding of economic inequality among people, which [economic inequality] is broader than just income inequality.

\section{Conceptual understanding of economic inequality among people}

In the authors' opinion, the conceptual understanding of economic inequality among people includes, first of all, an empirical interpretation of this concept, which makes it possible to practically measure and investigate this phenomenon. In the scientific literature, the authors managed to identify three main approaches to the conceptual understanding of what economic inequality among people is:

1) income-wealth approach (Stewart 1939; Piketty, Zucman 2014; Piketti 2015; World Inequality Database (WID) 2021);

2) resource-capital approach (Tikhonova 2006; Boronenko, Drezgic 2014; Mensikovs et al. 2020);

3) capability approach (Haq 1990; Sen 1985, 1992, 1997; Nussbaum 2003; Anand, Hees 2006; Nambiar 2013; Anand 2014; Robeyns 2020).

Income-wealth approach. The authors suppose that the first common association that arises when mentioning economic inequality among people is income inequality. But back in 1939, Ch. Stewart in the proceedings of the Conference on Research in National Income and Wealth "Studies in Income and Wealth" stressed that "national income and its distribution have thus far proved both more susceptible of measurement and more useful in economic analysis than national wealth and its distribution. But it seems that estimates of wealth, and its distribution by size classes, would prove of substantial independent value for economic analysis" (Stewart 1939).

The modern French economist T. Piketty has developeda methodology for inequality studies based on the idea of significance of wealth (capital, property - Piketti 2015) for assessing economic inequality among people. He outlined that income inequality 
in all societies results from a combination of two components: first, inequality in labor (pension) income, and second, inequality in capital (property) income (Piketti 2015). The more unequally each of these components is distributed, the higher the overall inequality. "The third determinant factor is the relationship between these two categories: do people with high labor incomes also receive high capital incomes? The stronger this relationship, expressed in a statistical ratio, the higher the inequality, all other conditions being equal" (Piketti 2015). The following figure presents the scheme of the conceptual understanding of economic inequality among people within the income-wealth approach.

Figure 1

\section{Conceptual understanding of economic inequality among people within the income-wealth approach}

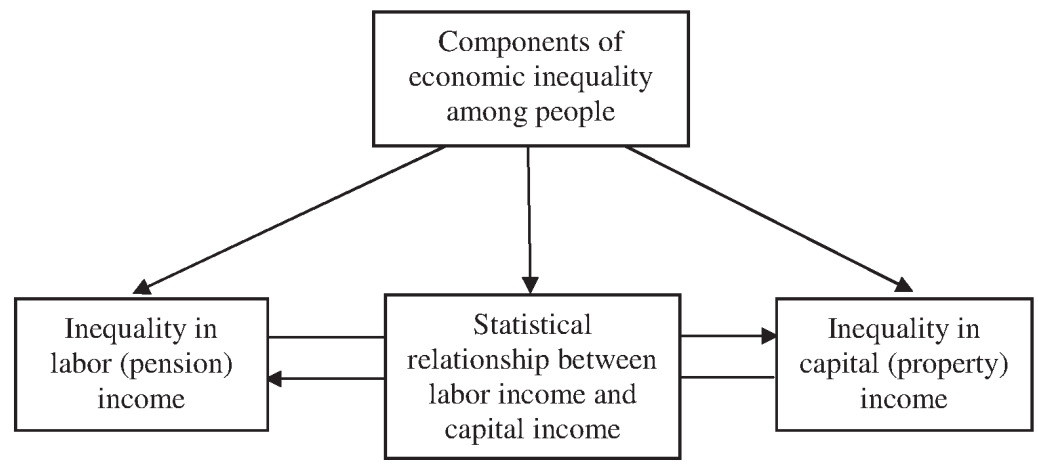

Source: elaborated by the authors based on Piketti 2015.

When investigating economic inequality, it is necessary to distinguish between these components (Figure 1) - both for normative and moral reasons (the issue of justifying inequality is posed in completely different ways when it comes to labor income, inheritance and return on capital), and because evolution in these aspects is determined by various economic, social and political mechanisms. When it comes to inequality in labor income, the acting mechanisms include supply and demand for qualifications, the state of the education system, and various normative acts and institutions that affect the functioning of the labor market and the formation of wages. When it comes to inequality in capital income, the key processes are the policy of savings and investment, the normative acts regulating the transfer and inheritance of property, the functioning of the financial and real estate markets. Very often, the statistics on inequality that economists use and which are referred to in public debate are generalized indicators, such as the Gini index, mixing together very different things, as a result of which it becomes impossible to clearly distinguish between the operating mechanisms and various facets of inequality (Piketti 2015).

One of the most important patterns that can be noted when measuring economic inequality is that inequality in capital (property) income is always much stronger than 
inequality in labor (pension) income (Piketii 2015). Ownership of capital and the income that flows from capital is much more concentrated than labor income (Piketty, Zucman 2014).

The same income-wealth terminology uses the World Inequality Database (WID), measuring income inequality, wealth inequality as well as wealth-income ratio among all ages people for the world's countries and regions (World Inequality Database (WID) 2021). For example, wealth-income ratio for all ages in Germany increased ${ }^{1}$ from 286.92 in 1960 to 489.92 in 2018, and in France - from 333.49 in 1960 to 597.31 in 2018 (World Inequality Database (WID) 2021).

Thus, the income-wealth approach makes it possible to empirically interpret economic inequality among people as, firstly, inequality of labor (pension) income, and secondly, inequality of wealth, that is, income from capital (property), which [income and wealth] are interconnected (character of this interconnection is the third determinant factor of economic inequality among people).

Resource-capital approach. The next approach to conceptual understanding of the economic inequality among people is the resource-capital approach (Tikhonova 2006; Boronenko, Drezgic 2014; Mensikovs et al. 2020), which is based on the following methodological path: resources available for the people and households can be transformed into capital as a result of its activation and capitalization that, in its turn, can give the person socially economic benefit, i.e. a resource becomes a capital. The application of the resource approach can be found in studies of different social sciences, sometimes revealing innovative resources or innovative forms of its activation and capitalization. Regional economics researchers used the resource approach in their studies (results of which have been published in this journal, proving that economic determinants of unequal competitiveness and development sustainability of territories are, firstly, resources available at the territory, and, secondly, ability of the territorial agents to transform them into territory capital) (Boronenko, Drezgic 2014).

One of the co-author of this article used the resource-capital approach in her previous team study (with colleagues from the Daugavpils University), applying this approach to measuring poverty of people based on the empirical data collected in one of the peripheral regions of Latvia - Latgale region (Mensikovs et al. 2020). As the result of this study three typological groups of the poor - "resource-poor", "functional-poor" and "resource-functional poor" - were identified. The first group, according to the logic of the resource-based approach, may include those people who have insufficient resources as such, whereas the second (most interesting for analysis) group includes people whose cause of poverty is not the lack of resources as such, but rather a low level of their capitalization. In turn, the third group of the poor - the "resourcefunctional poor" - may include those people whose lack of resources as such is accompanied by a low level of their capitalization. The results of the empirical analysis on the example of Latgale region of Latvia showed that the "resource-poor" make up

${ }^{1}$ The wealth-income ratio increases, by definition, when the rate of return on capital (assuming the return is fully reinvested) is greater than the rate of growth of the economy (Piketty, Zucman 2014). 
$74.2 \%$ of the total poor population of the region, and the "functional-poor" $-5.4 \%$. Every fifth $(20.4 \%)$ resident of Latgale region, acknowledged to be poor, suffers from a double burden of poverty: resource and functional one.

The scheme of the process of economic resources' capitalization and the corresponding measurements is presented in the following figure.

Figure 2

\section{Scheme of the process of converting economic resources into the economic capital}

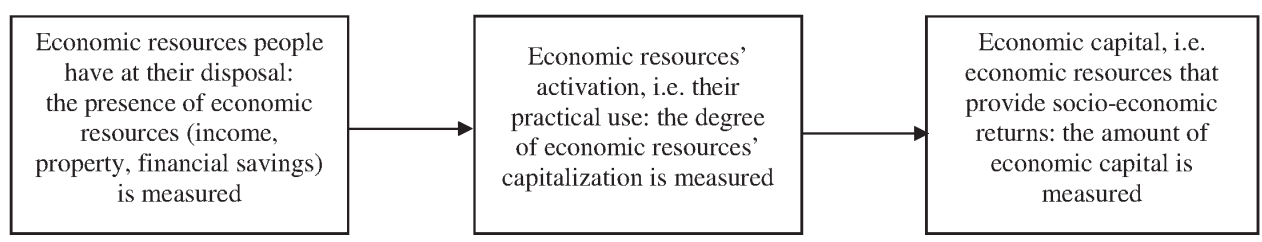

Source: elaborated by the authors based on Menshikov 2008, 2011; Mensikovs 2009; Men'shikov, Vanags 2011; Boronenko, Drezgic 2014; Mensikovs et al. 2020.

Thus, the resource-capital approach makes ir possible to empirically interpret economic inequality among people as, firstly, resource inequality, and secondly, capital inequality caused by both resource inequality and inequality of abilities and / or opportunities to capitalize available resources.

Capability approach. The last analyzed methodological approach to conceptual understanding of the economic inequality among people (which is partly related to the previous one in terms of abilities and / or opportunities to capitalize available resources) is the capability approach suggested by A. Sen, an Indian economist and philosopher, who since 1972 has been taught and worked in the United Kingdom and the United States. A. Sen promoted the methodological transition "from income inequality to economic inequality" (Sen 1997) in the framework of inequality studies, conceptually understanding economic inequality through inequality of capability.

The capability approach is a theoretical framework that entails two normative claims: first, the claim that the freedom to achieve well-being is of primary moral importance and, second, that well-being should be understood in terms of people's capabilities and functionings. Capabilities are the doings and beings that people can achieve if they so choose, such as being well-nourished, getting married, being educated, and travelling; functionings are capabilities that have been realized (Robeyns 2020). Whether someone can convert a set of means - resources and public goods - into a functioning (i.e. whether he/she has a particular capability) crucially depends on certain personal, sociopolitical and environmental conditions, which, in the capability literature, are called 'conversion factors' (Sen 1992; Nussbaum 2003; Nambiar 2013).

The measurement of capabilities was, in the early days, thought to be a particular barrier to the implementation and use of the approach (Sen 1985). However, in 1990, the UN Human Development report published possible capability measurement tool 
focused on health, education and income, which were equally weighted to generate the Human Development Index (HDI). The HDI is a summary measure of average achievement in key dimensions of human development: a long and healthy life, being knowledgeable and have a decent standard of living (Figure 2).

\section{The structure of the Human Development Index}

Figure 2

Human Development Index (HDI)
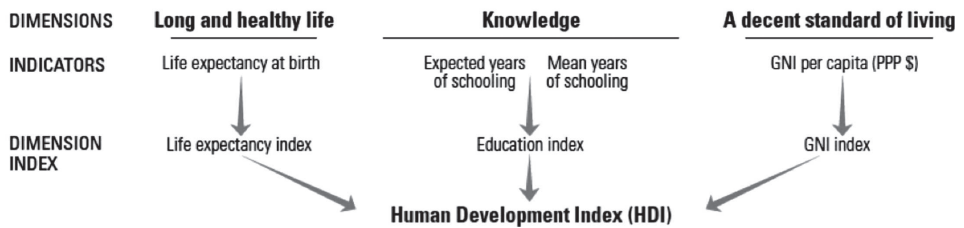

Source: UNDP 2021.

The Human Development Index was elaborated in 1990 by a Pakistani economist M. ul Haq in order to emphasize that people capabilities to obtain the desired level of health, education and income should be the ultimate criteria for assessing inequality (including economic) among people, not economic indicators alone (Haq 1990). At the same time, and subsequently, researchers recognizing that these three areas covered only certain elements of life quality have sought to develop more comprehensive capability measures. A major project in this area has been the 'capabilities measurement project' in which P. Anand has led teams of philosophers, economists and social scientists. The project dealt with the implementation of the capability approach, with particular emphasis on the key concepts developed in A. Sen (Sen 1985), as well as on further work with the content of the approach (Anand, Hees 2006; Anand 2014).

Sometimes researchers and organizations combine some of three aforementioned approaches to conceptual understanding of the economic inequality among people. For example, IZA World of Labor, an online platform that provides analytical materials for politicians, journalists, academics and society, defines economic inequality among people as the unequal distribution of income and opportunities between different groups of society (IZA World of Labor 2021), which is a combination of the incomewealth approach (in terms of income) and the capability approach. R. Dworkin in his study "What is Equality?" analyzed both equality of wealth (Dworkin 1981a) and equality of resources (Dworkin 1981b), combining the income-wealth approach (in terms of wealth) and the resource-capital approach (in terms of resources).

In fact, for empirical investigation of economic inequality among older people, the biggest challenge is not which of these three methodological approaches (or a combination of them) is more appropriate to apply to a more complete research on the above issue. The bigger problem is what statistics researchers can find on which empirical measures of economic inequality contained in all three approaches (especially in relation to the age group of older people). Thus, in their further empirical research within this article, the authors will try to empirically assess economic inequality among older people in the European Union, based on the available statistical or reliable socio- 
logical data (for the 65+ age group) according to any of the empirical criteria included in the methodological approaches analyzed above:

- income, wealth (income-wealth approach);

- economic resources, economic capital (resource-capital approach);

- Human Development Index, including health, education, income (capability approach).

\section{Empirical assessment of the economic inequality among older people in the European Union}

The authors will conduct an empirical assessment of economic inequality among older people in the European Union to test one of the key findings of the OECD study "Preventing Ageing Inequality", that economic inequality among younger people is nowadays much higher than for the older ones (OECD 2017). On the other hand, as mentioned in the introduction to this article, R. Jolly argues: "inequalities accrue and get reinforced over a person'slife" (Jolly 2014). Thus, the main empirical goal of the authors within this study is to find an evidence-based answer to the following research question: in the European Union, how great is the economic inequality among older people compared to the economic inequality among the population of other age groups, i.e. is economic inequality a distinctive feature of the $65+$ age group or is it common to the EU population as a whole, regardless of age?

OECD study "Preventing Ageing Inequality” provides statistics on Gini coefficient of disposable income inequality in OECD countries for the general population, as well as the $65+$ age group, which will definitely help the authors answer the above research question - at least for income dimension of economic inequality among people.

Table 2

Gini coefficient of disposable income inequality in some EU countries, the general population and the 65+ age group, 2014

\begin{tabular}{|c|c|c|c|}
\hline \multirow{2}{*}{ Countries* } & \multicolumn{2}{|c|}{$\begin{array}{c}\text { Gini coefficient of } \\
\text { disposable income inequality }\end{array}$} & \multirow{2}{*}{$\begin{array}{l}\text { Difference between } \\
\text { Gini coefficient } \\
\text { for the general population } \\
\text { and for the } 65+\text { age group }\end{array}$} \\
\hline & $\begin{array}{c}\text { for the general } \\
\text { population }\end{array}$ & $\begin{array}{l}\text { for the } 65+ \\
\text { age group }\end{array}$ & \\
\hline 1 & 2 & 3 & 4 \\
\hline Denmark & 0.254 & 0.225 & 0.029 \\
\hline Slovenia & 0.255 & 0.258 & -0.003 \\
\hline Finland & 0.257 & 0.244 & 0.013 \\
\hline Czech Republic & 0.262 & 0.190 & 0.072 \\
\hline Belgium & 0.268 & 0.228 & 0.040 \\
\hline Slovak Republic & 0.269 & 0.197 & 0.072 \\
\hline Austria & 0.280 & 0.275 & 0.005 \\
\hline Sweden & 0.281 & 0.271 & 0.010 \\
\hline
\end{tabular}

Sequel to Table 2 see on the next page 
Sequel to Table 2

\begin{tabular}{lccc}
\hline \multicolumn{1}{c}{$\mathbf{1}$} & $\mathbf{2}$ & $\mathbf{3}$ & $\mathbf{4}$ \\
\hline Luxembourg & 0.281 & 0.253 & 0.028 \\
\hline Netherlands & 0.283 & 0.235 & 0.048 \\
\hline Hungary & 0.288 & 0.228 & 0.060 \\
\hline Germany & 0.292 & 0.260 & 0.032 \\
\hline France & 0.294 & 0.297 & -0.003 \\
\hline Poland & 0.300 & 0.253 & 0.047 \\
\hline Ireland & 0.309 & 0.282 & 0.027 \\
\hline Italy & 0.325 & 0.297 & 0.028 \\
\hline Portugal & 0.342 & 0.323 & 0.019 \\
\hline Greece & 0.343 & 0.271 & 0.072 \\
\hline Spain & 0.346 & 0.290 & 0.056 \\
\hline Latvia & 0.352 & 0.308 & 0.044 \\
\hline United Kingdom & 0.358 & 0.322 & 0.036 \\
\hline Estonia & 0.361 & 0.269 & 0.092
\end{tabular}

Correlation** between the Gini coefficient of disposable income inequality for the general population (Column 1) and the difference between Gini coefficient for the general population and for the $65+$ age group (Column 3)

* Countries are ranked in ascending order according to the Gini coefficient of disposable income inequality for the general population.

$\because$ Despite the fact that theoretically the correlation analysis shows not the dependency of one variable on another, but their two-way interdependency (Biuiul', Tsefel' 2005), in this case the result will be logically interpreted as one-way dependency, since the Gini coefficient of disposable income inequality for the general population (Column 1) is a given (factorial) variable, but the difference between Gini coefficient for the general population and for the $65+$ age group (Column 3 ) is potentially dependent variable.

Source: elaborated by the authors based on OECD 2017; OECD.org 2021.

According to the data of Table 2, only in two of 22 countries of the EU-28 analyzed in the OECD study (in France and in Slovenia) the disposable income inequality within the $65+$ age group exceeds income inequality within the general population. Based on this evidence it can be preliminary concluded that the economic inequality among older people in the European Union is lower (excluding only some countries) compared to the average indicator of economic inequality among the EU population at least for income dimension of economic inequality. In turn, the results of the correlation analysis showed that there is a weak but statistically significant direct relationship between the Gini coefficient of disposable income inequality for the general population and the difference between this coefficient for the general population and for the $65+$ age group (Table 2). This means: the higher the disposable income inequality within the general population in a particular country, the more it is smoothed out (probably with the help of the social insurance system) for the 65+ age group. In other words, in the EU countries with the higher level of income inequality for the general population, older people stand out more against the background of the entire population of the 
country by their relative equality in incomes ${ }^{2}$ than in countries with a relatively low level of income inequality for the general population.

At the same time, in support of one of the key findings of the OECD study "Preventing Aging Inequality"(OECD 2017), the data of Table 2 show that the level of income inequality in the $65+$ age group does indeed vary widely across the 22 countries of the European Union: from 0.190 in the Czech Republic to 0.323 in Portugal (the difference between the minimum and maximum values is 0.133 ). In turn, the level of income inequality for the entire population of these countries varies slightly less - from 0.254 in Denmark to 0.361 in Estonia (the difference between the minimum and maximum value is 0.107$)$.

As outlined within income-wealth approach to conceptual understanding of economic inequality among people, "household income provides a partial view of the economic resources available to support people's consumption: it is also important to consider household wealth. Households can use wealth to consume more than their income, or may consume less than their income and add to their wealth. Wealth allows individuals to smooth consumption over time and to protect them from unexpected changes inincome. Households with reserves of wealth can also use them to generate capital income and to support a higher standard of living. While some wealth is held in assets that are not easily converted into money, its existence may allow people to borrow to finance expenditures, e.g. for house extensions, motor vehicle purchases, and so on" (Balestra, Tonkin 2018).

One of the key findings of the research by C. Balestra and R. Tonkin on inequalities in household wealth across OECD countries is that "levels of net wealth are strongly linked to people's life cycle, as wealth is built up over the course of working life and then reduced in retirement. Across the countries covered by the OECD Wealth Distribution Database, average household net wealth is highest amongst households where the head is aged between 55 and 64. Typically, this group is made up of people who are approaching, but not yet in retirement" (Balestra, Tonkin 2018). Although this finding does not refer to wealth inequality among older people, but rather confirms the assumption by T. Piketty that "on average, older people are richer than younger ones" (Piketti 2015).

In turn, regarding the subject of this research, T. Piketty argues (based on data of the World Inequality Database - World Inequality Database (WID) 2021) that "the concentration of property is almost as high within each age group as among the general population. In other words, contrary to popular belief, the war of age groups did not replace the war of social classes" (Piketti 2015). Since the authors have no other data on inequality in wealth among older people compared to the general population of the EU than those used by T. Piketty, the authors will answer a research question on economic inequality among older people in the European Union in comparison with the average indicator of economic inequality among the EU population in terms of wealth, based on the position of T. Piketty about the similarity of the concentration of wealth within each age group (Piketty 2015). Thus, in the European Union,

\footnotetext{
${ }^{2}$ Figuratively speaking, no matter how well you earn during your working career, in retirement years you will still be pretty much the same as everyone else's.
} 
economic inequality in terms of wealth is not a distinctive feature of the $65+$ age group, but characterizes all age groups of the EU population.

However, the authors have sociological data on economic resources and economic capital of people, which [data] can be used within the next methodological approach to conceptual understanding of the economic inequality among people - resourcecapital approach. The only limitation of this data is that they reflect the situation in just one country of the European Union - Latvia (in particular, Latgale region of Latvia, $\mathrm{n}=798$ respondents). At the same time, the great advantage of this data is that they relate to both economic resources and economic capital, and it is possible to compare the subsample of the $65+$ age group ( $n=63$ persons) with the rest of the respondents who belong to the $18-64$ age group ( $\mathrm{n}=735$ persons).

The list of economic resources, which includes real estate or movable property, financial savings and income (business, salary, social transfers, etc.) and refers to incomewealth approach, is developed by V. Menshikov, the sociologist of the Daugavpils University (Latvia) (Menshikov 2008, 2011; Mensikovs 2009), based on P. Bourdieu works (Bourdieu 1986). According to this methodology, which underlies the compilation of the sociological survey questionnaire (Daugavpils University 2017), the economic resources that are not only available to a respondent, but also bring him/her monetary income (in case of two first economic resources), social status or moral satisfaction as a result of resources' activation (using), are capitalized resources. In turn, capitalized economic resources all together constitute the economic capital of the respondent.

The following figure provides a visualized comparison of distributions of various economic resources in the 65+ age groupcompared to the 18-64 age group.

Figure 3

\section{Distribution of various economic resources in the $65+$ age group compared to the $18-64$ age group, $\%, n=798$ persons, Latgale region of Latvia, 2017}

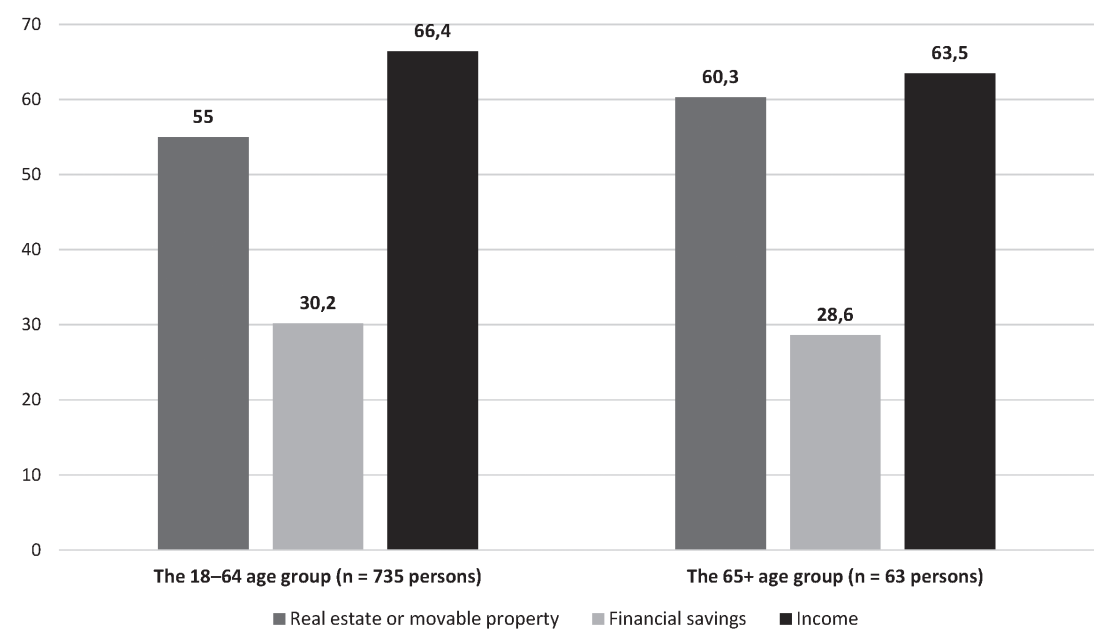

Source: elaborated by the authors based on Daugavpils University 2017. 
As the data in Figure 3 show, the pattern of the distribution of various economic resources in the 65+ age group is similar compared to the 18-64 age group. In both age groups, the main economic resource available to respondents is income, followed by real estate or movable property, then monetary savings.

The following figure provides a visualized comparison of distributions of economic resources' amount in the 65+ age group compared to the 18-64 age group.

Figure 4

\section{Distribution of economic resources' amount in the 65+ age group compared to the $18-64$ age group, $\%, n=798$ persons, Latgale region of Latvia, 2017}

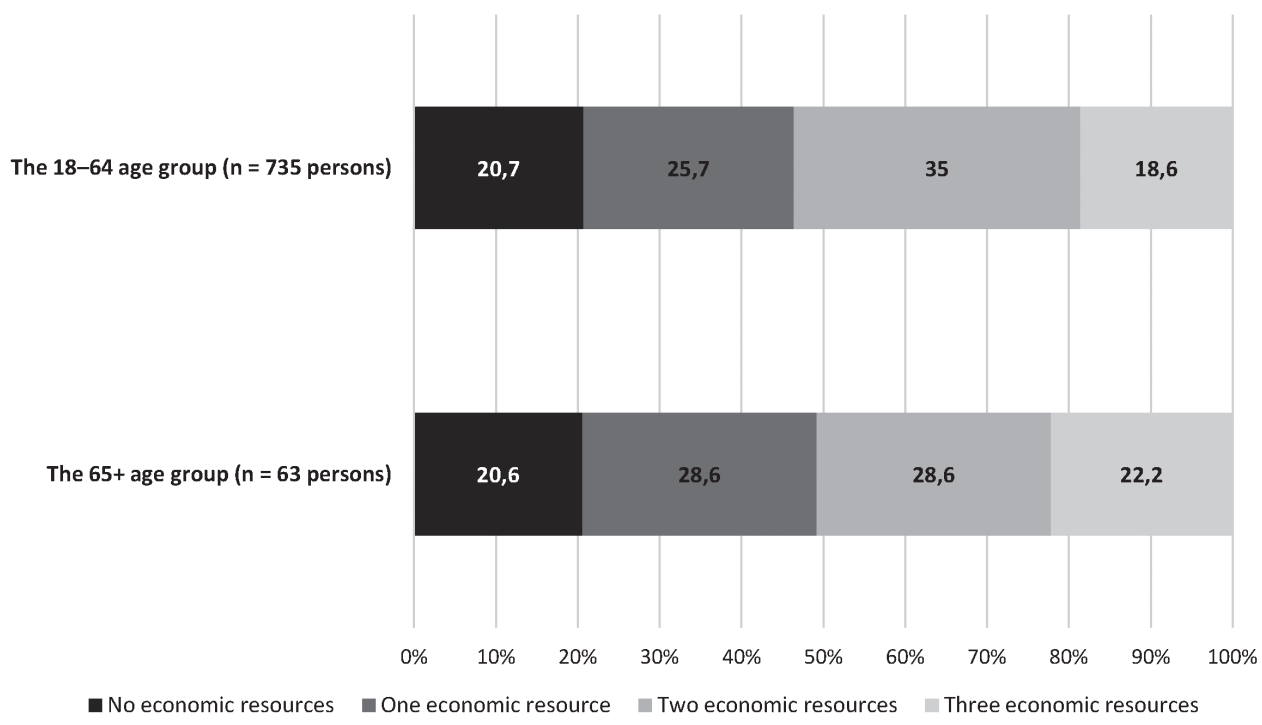

Source: elaborated by the authors based on Daugavpils University 2017.

As the data in Figure 4 show, the pattern of distribution of economic resources' amount in the 65+ age group, as in the previous case of various economic resources (Figure 3), is similar compared to the 18-64 age group. In both age groups, the most typical situation is when the respondent has at his/her disposal 1-2 economic resources, and in each age group about $20 \%$ of the respondents do not have any economic resources (that is, they are economically dependent on other people).

Since the visualized data do not provide a statistically correct answer for the research question, the authors also use Mann-Whitney $U$ test to define the statistical significance of differences in the intragroup distributions of economic resources across age groups of 18-64 and 65+. 


\section{Comparison of the intragroup distributions of economic resources across age groups of 18-64 and 65+, independent-samples Mann-Whitney $U$ test, $n=798$ persons, Latgale region of Latvia, 2017}

\begin{tabular}{lll}
\hline Economic resources & $\begin{array}{l}\text { Statistical significance } \\
\text { of difference between } \\
\text { age groups, p-value }\end{array}$ & $\begin{array}{c}\text { Conclusion on the statistical } \\
\text { significance* of differences } \\
\text { in the intragroup distributions of } \\
\text { economic resources across age groups }\end{array}$ \\
\hline $\begin{array}{l}\text { Real estate and } \\
\text { movable properties }\end{array}$ & $\mathrm{p}=0.412$ & $\begin{array}{l}\text { The distribution of real estate and } \\
\text { movable property is the same across age } \\
\text { groups }\end{array}$ \\
\hline Monetary savings & $\mathrm{p}=0.786$ & $\begin{array}{l}\text { The distribution of monetary savings is } \\
\text { the same across age groups }\end{array}$ \\
\hline $\begin{array}{l}\text { Income (business, } \\
\text { salary, social transfers) }\end{array}$ & $\mathrm{p}=0.641$ & $\begin{array}{l}\text { The distribution of income is the same } \\
\text { across age groups }\end{array}$ \\
\hline
\end{tabular}

* The significance level is 0.05 .

Source: elaborated by the authors based on Daugavpils University 2017.

As the data of statistical analysis show, the distribution of various economic resources (not the average amount of various resources, but the nature of their distribution that is, the level of economic inequality in terms of resources) does not statistically differ between the 65+ age group and the rest of the respondents (Table 3).

After the analysis of economic resources, the authors will analyze corresponding types of economic capital, which are capitalized resources, i.e. economic resources that are not only available to a respondent, but also bring him/her monetary income (in case of two first economic resources), social status or moral satisfaction as a result of resources' activation (using). In the framework of this study, a capitalized resource, i.e. capital, was empirically interpreted as one that brings the respondent at least one of the benefits: income, social status or moral satisfaction.

The following figure provides a visualized comparison of distributions of various types of economic capital in the 65+ age group compared to the 18-64 age group. 
Figure 5

\section{Distribution of various types of economic capital* in the $65+$ age group compared to the $18-64$ age group, $\%, n=798$ persons, Latgale region of Latvia, 2017}

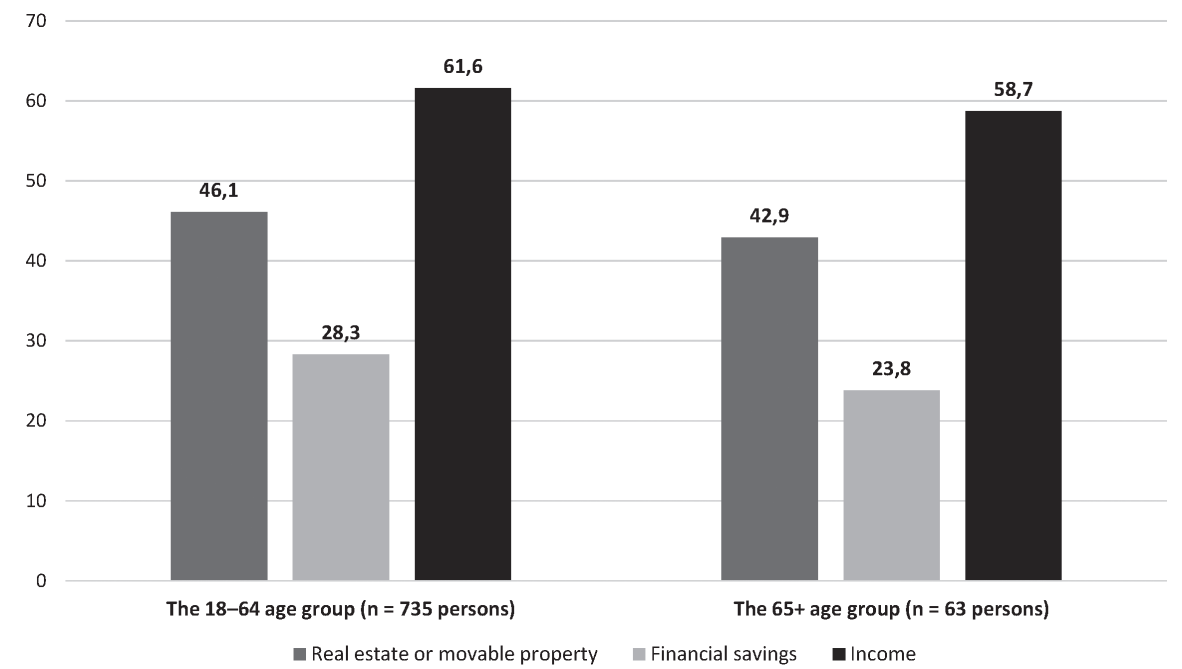

* Capitalized resources, i.e. economic resources that are not only available to a respondent, but also bring him/her monetary income (in case of two first economic resources), social status or moral satisfaction as a result of resouces' activation (using).

Source: elaborated by the authors based on Daugavpils University 2017.

As the data in Figure 5 show, the pattern of the distribution of various types of economic capital in the $65+$ age group is similar compared to the 18-64 age group. In both age groups, the main type of economic capital is income, followed by real estate or movable property, then monetary savings.

The following figure provides a visualized comparison of distributions of economic capital's amount in the 65+ age group compared to the 18-64 age group. 
Figure 6

Distribution of economic capital's* amount in the 65+ age group compared to the $18-64$ age group, $\%, \mathrm{n}=798$ persons, Latgale region of Latvia, 2017

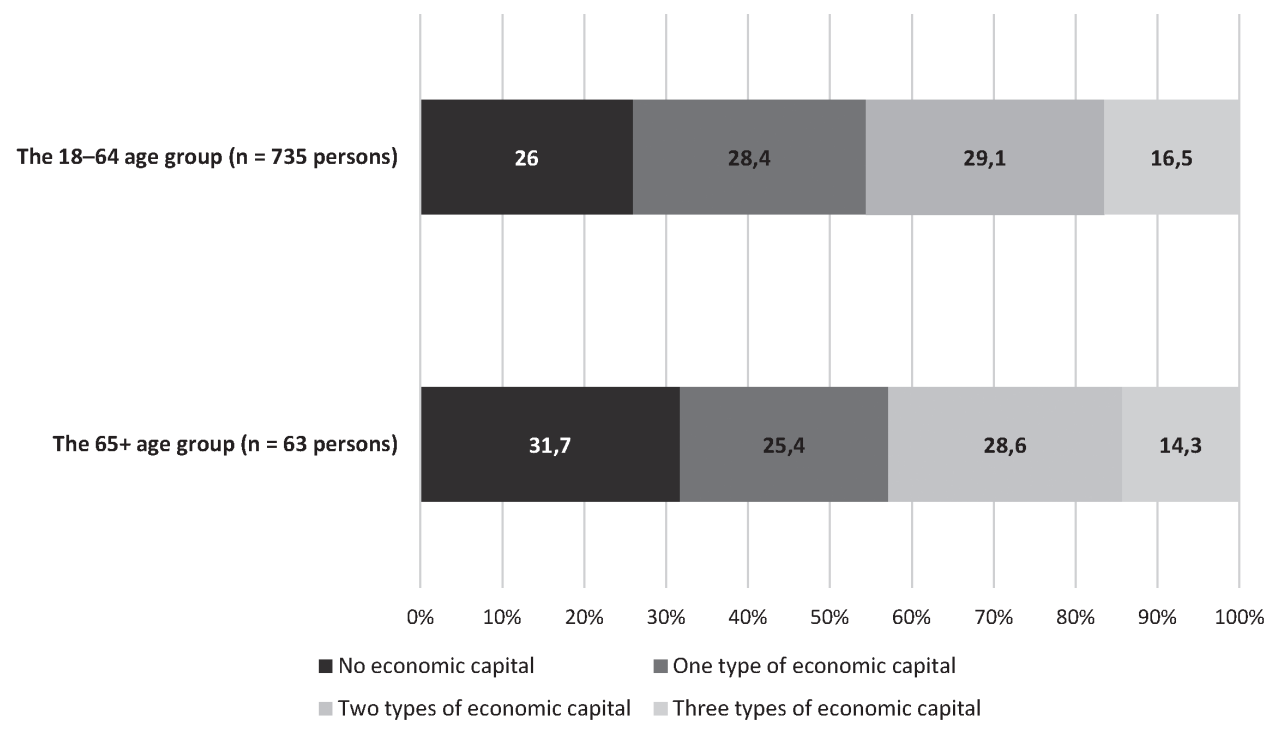

* Capitalized resources, i.e. economic resources that are not only available to a respondent, but also bring him/her monetary income (in case of two first economic resources), social status or moral satisfaction as a result of resouces' activation (using).

Source: elaborated by the authors based on Daugavpils University 2017.

As the data in Figure 6 show, the pattern of distribution of economic capital's amount in the $65+$ age group, as in the previous case of various types of economic capital (Figure 5), is similar compared to the 18-64 age group. In both age groups, the most typical situation is when the respondent has at his/her disposal 1-2 types of economic capital, and in each age group about $30 \%$ of the respondents do not have any type of economic capital (which is about $10 \%$ more than in the case of economic resources).

Since the visualized data do not provide a statistically correct answer for the research question, the authors also use Mann-Whitney U test to define the statistical significance of differences in the intragroup distributions of economic capital across age groups of 18-64 and 65+. 


\section{Comparison of the intragroup distributions of economic capital across age groups of 18-64 and 65+, independent-samples Mann-Whitney $\mathrm{U}$ test, $\mathrm{n}=798$ persons, Latgale region of Latvia, 2017}

\begin{tabular}{lcl}
\hline \multicolumn{1}{c}{$\begin{array}{c}\text { Types of } \\
\text { economic capital* }\end{array}$} & $\begin{array}{c}\text { Statistical significance } \\
\text { of difference between } \\
\text { age groups, p-value }\end{array}$ & $\begin{array}{c}\text { Conclusion on the statistical } \\
\text { significance** of differences } \\
\text { in the intragroup distributions of } \\
\text { economic capital across age groups }\end{array}$ \\
\hline $\begin{array}{l}\text { Real estate and } \\
\text { movable properties }\end{array}$ & $\mathrm{p}=0.618$ & $\begin{array}{l}\text { The distribution of real estate and } \\
\text { movable property is the same across age } \\
\text { groups }\end{array}$ \\
\hline Monetary savings & $\mathrm{p}=0.446$ & $\begin{array}{l}\text { The distribution of monetary savings is } \\
\text { the same across age groups }\end{array}$ \\
\hline $\begin{array}{l}\text { Income (business, } \\
\text { salary, social transfers) }\end{array}$ & $\mathrm{p}=0.650$ & $\begin{array}{l}\text { The distribution of income is the same } \\
\text { across age groups }\end{array}$ \\
\hline
\end{tabular}

* Capitalized resources, i.e. economic resources that are not only available to a respondent, but also bring him/her monetary income (in case of two first economic resources), social status or moral satisfaction as a result of resouces' activation (using).

$* *$ The significance level is 0.05 .

Source: elaborated by the authors based on Daugavpils University 2017.

As the data of statistical analysis show, the distribution of various types of economic capital (not the average amount of various types of capital, but the nature of their distribution - that is, the level of economic inequality in terms of capital) does not statistically differ between the 65+ age group and the rest of the respondents (Table 4).

As shown in the scheme of the process of converting economic resources into economic capital (Figure 2), within the resource-capital approach to the conceptual understanding of economic inequality among people, the degree of economic resources' capitalization is also measured. It may happen that the distribution of the degree of economic resources' capitalization in the 65+ age group differs from the 18-64 age group, and this may determine the fact that in the $65+$ age group there are slightly more of those who lack any economic capital (31.7\% versus $26.0 \%$ in the $18-64$ age group - Figure 6).

The degree of economic resources' capitalization is calculated using the following formula:

$$
\begin{gathered}
\text { DEGREE of capitalization }= \\
=\text { amount of economic capital } / \text { amount of economic resources }
\end{gathered}
$$

The following table provides a comparison of the degree of economic resources' capitalization between the 65+ and the 18-64 age groups, as well as the statistical significance of differences in the degree of economic resources' capitalization across age groups of $18-64$ and $65+$. 
Table 5

\section{Comparison of the degree of economic resources' capitalization across age groups of $18-64$ and $65+, \mathrm{n}=798$ persons, Latgale region of Latvia, 2017}

\begin{tabular}{|c|c|c|}
\hline $\begin{array}{l}\text { The degree of economic } \\
\text { resources' capitalization* }\end{array}$ & $\begin{array}{c}\text { The 18-64 age group } \\
(\mathrm{n}=735 \text { persons })\end{array}$ & $\begin{array}{l}\text { The } 65+\text { age group } \\
\text { ( } \mathrm{n}=63 \text { persons) }\end{array}$ \\
\hline 0.00 & $5.3 \%$ & $11.2 \%$ \\
\hline 0.33 & $0.3 \%$ & $0.0 \%$ \\
\hline 0.50 & $5.8 \%$ & $4.8 \%$ \\
\hline 0.67 & $1.9 \%$ & $6.3 \%$ \\
\hline 1.00 & $66.0 \%$ & $57.1 \%$ \\
\hline $\begin{array}{l}\text { No economic resources } \\
\text { for capitalization }\end{array}$ & $20.7 \%$ & $20.6 \%$ \\
\hline Total & $100.0 \%$ & $100.0 \%$ \\
\hline $\begin{array}{l}\text { Statistical significance of differences } \\
\text { in the degree of economic resources' } \\
\text { capitalization across age groups of } \\
18-64 \text { and } 65+\text {, Mann-Whitney U test }\end{array}$ & $\mathrm{p}=0.048 * *$ & $\begin{array}{l}\text { The distribution of the } \\
\text { degree of economic resour- } \\
\text { ces' capitalization is not } \\
\text { the same across age groups }\end{array}$ \\
\hline
\end{tabular}

* On a scale from 0 (the respondent has no capitalized economic resources) to 1 (all economic resources at the respondent's disposal are capitalized).

$*$ The significance level is 0.05 .

Source: elaborated by the authors based on Daugavpils University 2017.

The results of Mann-Whitney $U$ test show that there is a statistically significant difference between the 65+ age group and the rest of the respondents (although the p-value is very close to the 0.05 threshold - Table 5), indicating that the degree of economic resources' capitalization among older people and the rest of the respondents are distributed differently. The nature of these differences is also seen from the data in Table 5: among the older people there are 2 times more than among the rest of the respondents $(11.2 \%$ versus $5.3 \%)$ of those who have not been able to capitalize the economic resources at their disposal. Accordingly, among older people there are comparatively fewer than among the rest of the respondents $(57.1 \%$ versus $66.0 \%$ ), those who have managed to capitalize all the economic resources at their disposal.

Thus, the results of applying the resource-capital approach to the analysis of sociological data showed that in spite of the absence of statistically significant differences in the distributions of economic resources and economic capital across age groups of respondents, there is a statistically significant difference in the distribution of capability of younger and older people to convert economic resources into capital (that brings either material income, or social status, or moral satisfaction). In terms of the capability to capitalize economic resources, inequality among older people is statistically significantly higher than inequality among younger respondents.

In turn, the authors were unable to find data on the distribution in the European Union by age groups of such components of the Human Development Index as health 
and education, which, according to the capability approach, strongly influence the economic component of inequality among people. Nevertheless, the economic component of inequality among older people, in the authors' opinion, has been investigated in sufficient detail within this study, although using rather limited data.

\section{Conclusions}

The uniqueness of this study lies in the fact that the authors did not investigate the economic performance of older people in comparison with other age groups or the general population (there are many studies devoted to this), but they investigated economic inequality among older people versus economic inequality in other age groups / in the general population (subject to data availability).

Theoretically, economic inequality tends to be accumulated over life and should be stronger among older people than younger people or the general population. Nevertheless, the analysis of statistical and sociological data for the EU countries in the framework of various complementary methodological approaches to the conceptual understanding of economic inequality among people made it possible for the authors to conclude that both income and wealth are distributed among older people as unequally as this also occurs in other age groups of the population. The only statistically significant difference that the authors managed to identify concerns the capability to convert the economic resources at the disposal of people into economic capital: among older people there is more inequality in the degree of capitalization of economic resources than among younger people.

Thus, in the European Union, economic inequality (except for only one aspect) is not a distinctive feature of the age group of older people, but is practically the same as in other age groups or in the general population. Empirical evidence suggests that economic inequality is not accumulated over the course of a lifetime, but rather carries over from one period of life to another. Nevertheless, over the course of life, to a certain extent, the inability (or impossibility for various reasons) to capitalize economic resources, i.e. to convert them into economic capital is aggravated / accumulated.

\section{References}

Age International. (2014) Facing the Facts: The Truth About Ageing and Development. Available: https://www.ageinternational.org.uk/globalassets/documents/age-internationalfacing-the-facts-report.pdf (accessed on 31.05.2021).

Alpteker H. (2012) Who is Elderly? Available: https://www.researchgate.net/post/Who-is-elderly (accessed on 31.05.2021).

Anand P. (2014) Measuring progress in terms of quality of life: it can be done. Revista Internacional de Estadística y Geografía, Vol. 5, No. 3, pp. 96-98. Available: https://rde.inegi.org.mx/ rde_13/doctos/rde_13_art6.pdf (accessed on 31.05.2021).

Anand P., van Hees M. (2006) Capabilities and achievements. Journal of Socio-Economics, Vol. 35, pp. 268-284. DOI: https://doi.org/10.1016/j.socec.2005.11.003

Balestra C., Tonkin R. (2018) Inequalities in household wealth across OECD countries: evidence from the OECD Wealth Distribution Database. Working Paper No. 88 of the OECD Statistics 
and Data Directorate. Available: https://www.oecd.org/officialdocuments/publicdisplay documentpdf/?cote=SDD/DOC(2018)1\&docLanguage=En (accessed on 31.05.2021).

Biuiul'A., Tsefel'P. (2005) SPSS: Iskusstvo obrabotki informatsii. SPb.: DiaSoftIuP. (In Russian) Boronenko V., Drezgic S. (2014) Economic determinants of territory competitiveness and development sustainability. Socialo Zinatnu Vestnesis / Social Sciences Bulletin, Vol. 19, No. 2, pp. 44-67. Available: https://du.lv/wp-content/uploads/2016/01/SZF_vestnesis_2014_2.pdf (accessed on 31.05.2021).

Bourdieu P. (1986) The forms of capital. Richardson J. (Ed.) Handbook of Theory and Research for the Sociology of Education. New York: Greenwood, pp. 241-258.

Central Statistical Bureau of Latvia. (2021) Table MIS070: Mean disposable income per household member by age group and time period. Statistical Database. Available: https://data.stat. gov.lv/pxweb/en/OSP_PUB/START_POP_MI_MIS/MIS070/ (accessed on 31.05.2021).

Chan M. (2014) Healthy ageing is vital to social and economic development. Facing the Facts: The Truth About Ageing and Development. London: Age International. Available: https://www.ageinternational.org.uk/globalassets/documents/age-international-facing-the-factsreport.pdf (accessed on 31.05.2021).

Cochrane Ch., Perrella A. (2012) Regions, regionalism and regional differences in Canada. Canadian Journal of Political Science, Vol. 45, No. 4, pp. 829-853. DOI: https://doi.org/ 10.10170S0008423912001011

Daugavpils University. (2017) Resources and Capital of Latgale Region (Latvia) Population. Dataset of the sociological survey, Latgale region (Latvia), $\mathrm{n}=798$ respondents, SPSS data file. Available by request: vera.komarova@du.lv.

Dworkin R. (1981a) What is equality? Part 1: Equality of welfare. What is equality? Part 2: Equality of resources. Philosophy and Public Affairs, Vol. 10, No. 3, pp. 185-246. Available: http://links.jstor.org/sici?sici=0048-3915\%28198122\%2910\%3A3\%3C185\%3AWIEP1E\% 3E2.0.CO\%3B2-7 (accessed on 31.05.2021).

Dworkin R. (1981b) What is equality? Part 2: Equality of resources. Philosophy and Public Affairs, Vol. 10, No. 4, pp. 283-345. Available: http://links.jstor.org/sici?sici=0048-3915\% $28198123 \% 2910 \% 3$ A4\%3C283\%3AWIEP2E\%3E2.0.CO\%3B2-3 (accessed on 31.05.2021).

European Commission. (2013) Demography and Inequality: How Europe's Changing Population Will Impact on Income Inequality. Available: https://ec.europa.eu (accessed on 31.05.2021).

Eurostat. (2021) Population structure and ageing. Statistics Explained. Available: https://ec. europa.eu/eurostat/statistics-explained/index.php?title=Population_structure_and_ageing\# The_share_of_elderly_people_continues_to_increase (accessed on 31.05.2021).

Glinskiy V., Serga L., Novikov A., Litvintseva G., Bulkina A. (2017) Investigation of correlation between the regions sustainability and territorial differentiation. Procedia Manufacturing, Vol. 8, pp. 323-329. DOI: https://doi.org/10.1016/j.promfg.2017.02.041

Granberg A. (1999) Differentiation of regions of Russia on gross regional product by expenditures. 39th Congress of the European Regional Science Association: Regional Cohesion and Competitiveness in $21^{\text {st }}$ Century Europe”, August 23-27, Dublin, Ireland. Louvain-la-Neuve: European Regional Science Association (ERSA). Available: https://www.econstor.eu/dspace/ bitstream/10419/114305/1/ERSA1999_a217.pdf (accessed on 31.05.2021).

Granberg A., Masakova I., Zaitseva I. (1998) Gross regional product as the indicator of differentiation of social-economic development of the regions (Russia in transition). $38^{\text {th }}$ Congress of the European Regional Science Association: Europe Quo Vadis? - Regional Questions at the Turn of the Century”, 28 August - 1 September, Vienna, Austria. Louvain-la-Neuve: Euro- 
pean Regional Science Association (ERSA). Available: https://www.econstor.eu/handle/10419/ 113445/ (accessed on 31.05.2021).

Grinfelde A. (2010) Pensionaru dzives kvalitate Latvijas regionos: Promocijas darbs. Jelgava: Latvijas Lauksamniecibas universitate. Available: https://lufb.llu.lv/disertacijas/ economics/Anda_Grinfelde_promocijas_darbs_2010_LLU_EF.pdf (accessed on 31.05.2021). (In Latvian)

ul Haq M. (1990) Human Development Report 1990. United Nation Development Programme. Available: http://hdr.undp.org/sites/default/files/reports/219/hdr_1990_en_complete_ nostats.pdf (accessed on 31.05.2021).

IZA World of Labor. (2021) What is economic inequality? Key Topic. Available: https://wol. iza.org/key-topics/economic-inequality (accessed on 31.05.2021).

Jolly R. (2014) Inequality and ageing. Facing the Facts: The Truth About Ageing and Development. London: Age International. Available: https:/www.ageinternational.org.uk/globalassets/ documents/age-international-facing-the-facts-report.pdf (accessed on 31.05.2021).

Karwat-Wozniak B. (2011) Regional differentiation in the socio-economic development conditions of the agriculture in Poland. Economics \& Sociology, Vol. 4, No 2, pp. 11-25. Available: https://www.economics-sociology.eu/files/E\&S_4_2_guest.pdf (accessed on 31.05.2021).

Kim S. (2008) Spatial inequality and economic development: theories, facts and policies. Commission on Growth and Development Working Paper No. 16. Washington: The World Bank. Available: https://openknowledge.worldbank.org/handle/10986/28050 (accessed on 31.05.2021).

Kovacevic M. (2010) Measurement of inequality in human development - a review. United Nations Development Programme Human Development Reports Research Paper 2010/35. Available: http://hdr.undp.org/sites/default/files/hdrp_2010_35.pdf (accessed on 31.05.2021). Kozyreva P., Zhu D., Nizamova A., Smirnov A. (2021) Justice and inequality in the household consumption in Russia and China: a comparative analysis. RUDN Journal of Sociology, Vol. 21, No. 1, pp. 50-67. DOI: https://doi.org/10.22363/2313-2272-2021-21-1-50-67

Krastins O. (2000) Teritoriala noslanosanas ir mazaka neka sociala. Tomer liela. Latvijas Vestnesis, 19. oktobris, Nr. 368/369, 14. lpp. (In Latvian)

Kuttor D. (2009) Territorial inequalities in Central Europe: spatial analysis of the Visegrad countries. Romanian Review of Regional Studies, Vol. V, No. 1. Available: https://core.ac.uk/ download/pdf/27060466.pdf (accessed on 31.05.2021).

Kuznets S. (1955) Economic growth and income inequality. American Economic Review, Vol. 45, pp. 1-28. Available: https://www.jstor.org/stable/1811581 (accessed on 31.05.2021). Kvícalova J., Mazalova V., Siroky J. (2014) Identification of the differences between the regions of the Czech Republic based on the economic characteristics. Procedia Economics and Finance, Vol. 12, pp. 343-352. DOI: https://doi.org/10.1016/S2212-5671(14)00354-2

Menshikov V. (2008) Capital in sociological aspect: theoretical bases of investigation and operational parameters. Partycki S. (Ed.) Kultura a rynek. Lublin: KUL, pp. 180-186.

Menshikov V. (2011) Human capital in the structure of total capital of personality: sociological aspect. Filosofija. Sociologija, Vol. 22, No. 2, pp. 150-161. Available: http://mokslozurnalai. lmaleidykla.lt/publ/0235-7186/2011/2/149-160.pdf (accessed on 31.05.2021).

Mensikovs V. (2009) Kopkapitals un jaunatnes dzives strategijas: sociologiskais aspekts. Socialo Zinatnu Vestnesis, Nr. 9(2), 7.-37. lpp. Available: https://du.lv/wp-content/uploads/2016/01/ SZV_2009_2.pdf (accessed on 31.05.2021). (In Latvian)

Mensikovs V., Kokina I., Komarova V., Ruza O., Danilevica A. (2020) Measuring multidimensional poverty within the resource-based approach: a case study of Latgale region, Latvia. 
Entrepreneurship and Sustainability Issues, Vol. 8, No. 2, pp. 1211-1227. DOI: http://doi.org/ 10.9770/jesi.2020.8.2(72)

Mensikovs V., Lavrinovica I. (2011) Socialas diferenciacijas tendences musdienu Latvija. Proceedings of the $53^{\text {rd }}$ International Scientific Conference of Daugavpils University. Available: https://www.dukonference.lv/files/proceedings_of_conf/53konf/ekonomika/Mensikovs_ Lavrinovica.pdf (accessed on 31.05.2021). (In Latvian)

Men'shikov V., Vanags E. (2011) Mezhdunarodnaia trudovaia migratsiia: poisk metodologicheskih osnovanii empiricheskogo issledovaniia. Socialo Zinatnu Vestnesis / Vestnik sotsial'nykh nauk, Vol. 13, No. 2, pp. 45-70. Available: (accessed on 31.05.2021). (In Russian)

Meusburger P. (2001) Spatial and social disparities of employment and income in Hungary in the 1990s. Meusburger P., Jons H. (Eds.) Transformations in Hungary. Essays in Economy and Society. Heidelberg: Physica Verlag, pp. 173-206. Available: https://www.springer.com/ gp/book/9783642575846 (accessed on 31.05.2021).

Nambiar S. (2013) Capabilities, conversion factors and institutions. Progress in Development Studies, Vol. 13, No. 3, pp. 221-230. DOI: https://doi.org/10.1177/1464993413486547

Nussbaum M. (2003) Capabilities as fundamental entitlements: Sen and social justice. Feminist Economics, Vol. 9, No. 2-3, pp. 33-59. DOI: https://doi.org/10.1080/1354570022000077926 OECD. (2017) Preventing Ageing Inequality. Paris: OECD Publishing. DOI: https://doi.org/ 10.1787/9789264279087-en

OECD.org. (2021) OECD Income Distribution Database (IDD): Gini, Poverty, Income, Methods and Concepts. Available: https://www.oecd.org/social/income-distribution-database.htm (accessed on 31.05.2021).

Orimo H., Suzuki T., Hosoi T., Ito H., Araki A., Sawabe M. (2006) Reviewing the definition of 'elderly'. Geriatrics and Gerontology International, Vol. 6, pp. 149-158. DOI: https://doi. org/10.1111/j.1447-0594.2006.00341.x

Piketti T. (2015) Kapital v XXI veke. Moskva: Ad Marginem Press (in Russian).

Piketty T., Zucman G. (2014) Capital is back: wealth-income ratios in rich countries 17002010. Quarterly Journal of Economics, Vol. 129, Issue 3, pp. 1255-1310. DOI: https:/doi.org/ 10.1093/qje/qju018

Rice P., Venables A. (2004a) Productivity: Understanding Regional Differences. Available: http://cep.lse.ac.uk/pubs/download/CP162.pdf (accessed on 31.05.2021).

Rice P., Venables A. (2004b) Spatial determinants of productivity: analysis for the regions of Great Britain. CEP Discussion Paper No. 642. Available: http://cep.lse.ac.uk/pubs/download/ dp0642.pdf (accessed on 31.05.2021).

Robeyns I. (2020) The capability approach. Stanford Encyclopedia of Philosophy. Available: https://plato.stanford.edu/entries/capability-approach/ (accessed on 31.05.2021).

Selivanova-Fjodorova N. (2020) Latvijas regionu ekonomiska diferenciacija 21. gadsimta sakuma: Promocijas darbs. Daugavpils: Daugavpils Universitate. Available: https://du.lv/wp-content/ uploads/2020/03/Selivanova-Fjodorova-Promocijas-darbs.pdf (accessed on 31.05.2021). (In Latvian)

Selivanova-Fyodorova N., Komarova V., Lonska J., Mietule I. (2019) Differentiation of internal regions in the EU countries. Insights into Regional Development, Vol. 4, No. 1, pp. 370-384. DOI: https://doi.org/10.9770/ird.2019.1.4(7)

Sen A. (1985) Commodities and Capabilities. Oxford: Oxford University Press.

Sen A. (1992) Inequality Reexamined. Oxford: Clarendon Press. 
Sen A. (1997) From income inequality to economic inequality. Southern Economic Journal, Vol. 64, No. 2, pp. 383-401. Available: https://www.jstor.org/stable/1060857 (accessed on 31.05.2021).

Stewart Ch. (1939) Income capitalization as a method of estimating the distribution of wealth by size groups. Studies in Income and Wealth, Vol. 3. NBER, pp. 95-146. Available: https://www.nber.org/system/files/chapters/c9522/c9522.pdf (accessed on 31.05.2021).

Tikhonova N. (2006) Resursnii podkhod kak novaia teoreticheskaia paradigma $\mathrm{v}$ stratifikatsionnykh issledovaniiakh. Sotsiologicheskie issledovaniia, № 9, s. 28-41. Available: http://ecsocman.hse.ru/data/022/785/1219/Sotsis_09_06_p28-41.pdf (accessed on 31.05.2021). (In Russian)

UNDESA. (2016) Economic Inequalities in Old Age. Available: https://www.un.org/ development/desa/ageing/wp-content/uploads/sites/24/2016/08/Briefing-Paper_EconomicInequalities_Final.pdf (accessed on 31.05.2021).

UNDP. (2021) Human Development Index (HDI). United Nations Development Programme. Available: http://hdr.undp.org/en/content/human-development-index-hdi (accessed on 31.05.2021).

World Inequality Database (WID). (2021) WID. world Data. Available: https://wid.world/ data/ (accessed on 31.05.2021). 